\title{
REDUCING THE HARMFUL EFFECTS OF SANITARY WATER ON GROWTH AND QUALITY OF SOME ECONOMIC TREES USING JASMINE OIL
}

\author{
S.M. Shahin and A.S. Tawila \\ Botanical Gardens Res. Dept., Hort. Res. Inst., ARC, Giza, Egypt. \\ ABSTRACT: An experiment was undertaken in the open field at the \\ nursery of Hort. Res. Inst., ARC, Giza, Egypt during 2013 and 2014 \\ seasons to explore the effect of different water qualities (fresh, mixed (50\% \\ fresh $+50 \%$ sanitary water) and primary treated sanitary water), various \\ concentrations of jasmine oil $(0.0,0.03$ and $0.05 \%)$ applied as foliar spray, \\ 3 times with 15 days interval and their interactions on growth and chemical \\ composition of one-year-old seedlings of Australian pine (Casuarina \\ equisetifolia L.) and River Red Gum (Eucalyptus rostrata Schlecht.)

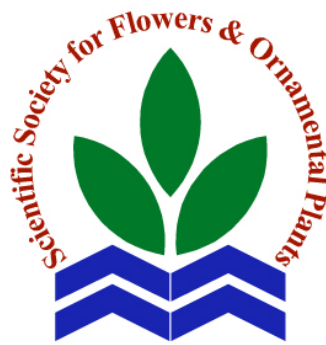 \\ Scientific J. Flowers \& \\ Ornamental Plants, \\ 2(1):67-84 (2015). \\ Received: \\ $7 / 12 / 2014$ \\ Revised by: \\ Prof. Dr. Eman M. Abou \\ El-Ghait, Banha Univ. \\ Prof. Dr. M.M. Farahat, \\ Agric. \& Biol. Res. Div., \\ NRC. \\ cultivated in 16-cm-diameter black polyethylene bags filled with about 3.5 \\ $\mathrm{kg}$ of clayey soil. \\ The obtained results have shown that all vegetative and root growth \\ parameters of the used two trees were significantly increased in response to \\ the different sole treatments and interactions used in this study. A similar \\ trend was also obtained concerning the leaf content of chlorophyll $\mathrm{a}, \mathrm{b}$ and \\ carotenoids, as well as total soluble sugars, N, P and K in the stem, leaves \\ and roots, as they were markedly increased by the various employed \\ treatments. On the other hand, content of $\mathrm{Pb}$ and $\mathrm{Cd}$ in the stem, leaves and \\ roots was increased as the level of sanitary water increased in irrigation \\ water, but they were gradually decreased with increasing jasmine oil \\ concentration in spray solution. In general, content of these two metals in \\ various plant organs was greatly less than their critical levels that induce \\ toxicity. So, no morpho-or physio-logical disorders appear on the plants of \\ the two studied tree species. However, the prevalence in all previous \\ measurements was for the combining between irrigation with mixed water \\ and spraying with $0.05 \%$ jasmine oil solution, as this combination gave the \\ best rate of vegetative and root growth and the highest content of pigments, \\ total soluble sugars, $\mathrm{N}, \mathrm{P}$ and $\mathrm{K}$ in plant tissues accompanied with the least \\ content of $\mathrm{Pb}$ and $\mathrm{Cd}$ elements. \\ Hence, it could be said that primary treated sanitary water can be used \\ after mixing with fresh water at equal parts in irrigation Casuarina \\ equisetifolia L. and Eucalyptus rostrata Schlecht. plants proved spraying \\ them with $0.05 \%$ jasmine oil solution, 3 times with 15 days interval to \\ achieve the best growth and highest quality.
}

\section{INTRODUCTION}

Casuarina equisetifolia L., Australian pine (Fam. Casuarinacae) and Eucalyptus

Key words: Casuarina equisetifolia L., Eucalyptus rostrata Schlecht., sanitary water, jasmine oil, vegetative and root growth, chemical composition, water quality.

rostrata Schlecht., River Red Gum (Fam. Myrtaceae), both are native to Australia, cultivated on canals, agricultural roads, avenues and belts. They are also grown for shading, erosion prevention and for wind 


\section{S.M. Shahin and A.S. Tawila}

breaking. Their wood is used for fuel and charcoal, as well as for wood industry (Bailey, 1976 and Huxley et al., 1992).

Although reuse of sanitary water for irrigation proved to have some disadvantages on some plants, it has some beneficial effects on other ones, especially economic ornamentals which are not food chain crops. In this respect, Verma et al. (1991) found that irrigation with municipal effluent caused significant increases in height, girth, branch and leaf number, and in dry matter production of Eucalyptus tereticornis and Lucaena leucocephala. Likewise, were the results of Kanekar et al. (1993) on Acacia nilotica and Casuarina equisetifolia, Poraas (2000) on Eucalyptus batryoides and Casuarina tenussima, Abbas (2002) on Casuarina glauca, Populus nigra and Taxodium distichum and Hassan (2005) who revealed that primary treated sewage water significantly increased plant height, stem diameter, leaves and branches No., leaf area and fresh dry weights of leaves, shoots and roots of Khaya senegalensis, Swiettenia mahogony and Taxodium distichum. Specific gravity and fiber length took the same trend of vegetative growth in the 3 timber species. This water also gave the significantly high values of total chlorophyll content, $\mathrm{N}, \mathrm{P}, \mathrm{K}, \mathrm{Na}, \mathrm{Cu}, \mathrm{Mn}, \mathrm{Zn}, \mathrm{Cd}, \mathrm{Ni}, \mathrm{Pb}$ and $\mathrm{Fe}$ concentrations in the different plant parts of the 3 trees. Other benefits were also recorded by Gogate et al. (1995) on teak (Tectona grandis), Shahin and Poraas (2005) on Dodonaea viscosa, Shahin and El-Malt (2006) on Acacia nilotica, Quercus suber and Tipuana Tipu, Abdalla (2007) on bird-ofparadise and carnation and Odindo et al. (2013) on Phaseolus vulgaris and Beta vulgaris.

It is well known that jasmonates are important signaling molecules for plant defensive responses upon mechanical wounding, herbivory damage or fungal inoculation. This was emphasized by Naidoo et al. (2013) on Eucalyptus grandis, Moreira et al. (2012) on Pinus pinaster, Semiz et al. (2012) on Pinus sylvestris and Quercus ilex, Boeckler et al. (2013) on Populus nigra and
Lombardero et al. (2013) on Pinus pinaster and $P$. radiata. Furthermore, Kondo (2010) mentioned that jasmonates are able to regulate ethylene biosynthesis and aroma volatiles in the skin of apples and pears, and increased ester and alcohol production in fruits. Jasmonates have a role in plant defense against environmental stress, where the application of N-propyl dihydrojasmonates (PDJ), a jasmonic acid (JA) derivative, decreased low-temperature injuries such as splitting and spotting in apple fruits. PDJ application also induced stomatal closure in citrus leaves. Likewise, Gonzalez-Aguilar et al. (2003) stated that methyl jasmonate (MeJA) application reduced chilling injuries in Carica papaya.

Another physiological effects were also observed by Nojiri et al. (1992) who postulated that jasmonates promoted bulb formation and development in onion and Koda et al. (1998) who revealed that jasmonates stimulated potato tuberization. Moreover, Tamari et al. (1995) claimed that jasmonates induced the pigmentation and flavonoid gave expression in Petunia hybrida corollas. Kondo and Yazama (2004) reported that JA stimulated callus formation on apple pulp discs and promoted anthocyanin accumulation in apple fruit skin. Kondo (2010) affirmed that PDJ application increased fruit coloration in apples.

Other results indicated that dipping of carnation cut-flowers in jasmine oil at $0.03 \%$ enhanced flower quality and prolonged vase life by improving water uptake, reducing depletion of sugars content and pigments in the leaves (Zaky and El-Zayat, 2008). Ahmed et al. (2010) noticed that spraying jasmine oil solution at $0.03 \%$ concentration on foliage of Phoenix canariensis and Latania lontaroides palms gave better growth and higher content of chlorophyll a, b, carotenoids, total carbohydrates and indoles than NPK mixture at $2.5 \mathrm{~g} /$ pot. These observations were supported by results of Zabala et al. (2010) on Thevetia peruviana, Lovatt and Zheng (2010) on Pistacia vera, Shafiq et al. (2011) on "Cripps Pink" apple, Moreira et al. (2012) on Pinus pinaster, 
Gong et al. (2012) on Ziziphus jujupe, Shafiq et al. (2013) on "Cripps Pink" apple, Ozturk et al. (2013) on "Fuji" apples and Sunil et al. (2014) on loquat (Eriobotrya japonica).

The present work, however aims to reveal the role of jasmine oil in improving growth and quality plus enhancing tolerance ability of Casuarina and Eucalyptus trees to hazards of sanitary water when use at various strengths for irrigation.

\section{MATERIALS AND METHODS}

A trial was carried out in the open field at the nursery of Hort. Res. Inst. ARC, Giza, Egypt throughout the two consecutive seasons of 2013 and 2014 to study the effect of irrigation with sanitary water, foliar spray with jasmine oil and their interactions on growth performance and chemical composition of Australian Pine and River Red Gun seedlings.

Thus, homogenous one-year-old seedlings of both Casuarina equisetifolia L. and Eucalyptus rostrata Schlecht. of about $35 \mathrm{~cm}$ length were planted on April, $1^{\text {st }}$ for each season in 16-cm-diameter black polyethylene bags filled with about $3.5 \mathrm{~kg}$ of clayey soil. Some physical and chemical properties of the clay used in the two seasons were determined and illustrated in Table (1).

The seedlings were irrigated immediately after planting with $1500 \mathrm{ml}$ of the following 3 different water quality.

1- Fresh water as a control (E.C. $=0.47$ $\left.\mathrm{dSm}^{-1}\right)$.

2- Primary treated sanitary water obtained from Zenein Waste Water Treatment Plant, Zenein, Giza. The chemical properties and pathological characteristics in 3 samples of the used sanitary water are shown in Tables (2) and (3), respectively.

3- A mixture of fresh and sanitary water at equal volume $(1: 1, \mathrm{v} / \mathrm{v})$ used as a mixed water treatment.

Throughout the course of this study, plants were irrigated once every 2 days with $350 \mathrm{ml}$ of the various water qualities used.
Jasmine oil (the essential oil extracted from flowers of Jasminum grandiflorum, which contains the main following components: cis-3-hexanol (3\%), cis-3hexenylacetate $(4.5 \%)$, linalool L $(59 \%)$, benzyl acetate $(22.5 \%)$, methyl anthranilate $(1.5 \%)$, methyl salicylate (2\%), methyl benzoate $(4.5 \%)$ and benzyl benzoate (3\%), besides variable amounts of indole, cisjasmane, geraniol, P-cresol, farnesol, eugenol, nerol, benzoic acid, benzaldehyde, Beale and Ward (1998) was dissolved in $20 \%$ ethanol and sprayed as an aqueous solution on the foliage of treated plants till the solution was run-off after one month from planting (on May $1^{\text {st }}$ ), 3 times with 15 days interval at the concentrations of 0.00 , 0.03 and $0.05 \%$.

Each type of water was combined with each level of jasmine oil to form 9 interaction treatments.

The plants of each tree species were arranged for each season in randomized block design with factorial concept replicated thrice, as each replicate contained 5 seedlings, i.e., 15 seedlings in each treatment (Mead et al., 1993). All plants under various treatments received the usual agricultural practices whenever required.

At the end of each season (on October, $30^{\text {th }}$ ), data were recorded as follows: plant height $(\mathrm{cm})$, number of leaves/plant, stem diameter at the base $(\mathrm{cm})$, number of branches/plant, root length $(\mathrm{cm})$, number of rootlets/main root as well as fresh and dry weights of stem, leaves and roots $(\mathrm{g})$. In fresh leaf samples taken from the middle parts of the plants in the $2^{\text {nd }}$ season only, photosynthetic pigments content (chlorophyll a, b and carotenoids, $\mathrm{mg} / \mathrm{g}$ f.w.) was determined according to the method of Moran (1982), while in dry samples of stem, leaves and roots, the percentages of total soluble sugars (Dubois et al., 1956), nitrogen (Pregl, 1945), phosphorus (Luatanab and Olsen, 1965), potassium (Jackson, 1973) as well as the content of lead $(\mathrm{Pb})$ and cadmium $(\mathrm{Cd})$ in ppm (Jackson, 1973) were measured. 
Table 1. Some physical and chemical properties of clay used in the two seasons.

\begin{tabular}{|c|c|c|c|c|c|c|c|c|c|c|c|c|c|c|}
\hline \multirow[b]{2}{*}{ Season } & \multicolumn{4}{|c|}{ Practical size distribution (\%) } & \multirow[b]{2}{*}{ S.P. } & \multirow[b]{2}{*}{ pH } & \multirow[b]{2}{*}{ E.C. } & \multicolumn{4}{|c|}{ Cations (meq/l) } & \multicolumn{3}{|c|}{ Anions (meq/l) } \\
\hline & $\begin{array}{c}\text { Coarse } \\
\text { sand }\end{array}$ & $\begin{array}{l}\text { Fine } \\
\text { sand }\end{array}$ & Silt & Clay & & & & $\mathrm{Ca}^{++}$ & $\mathbf{M g}^{++}$ & $\mathbf{N a}^{+}$ & $\mathbf{K}^{+}$ & $\mathrm{HCO}_{3}^{-}$ & $\mathrm{Cl}^{-}$ & $\mathrm{SO}^{--}$ \\
\hline 2013 & 7.54 & 22.28 & 30.55 & 39.63 & 55.00 & 8.0 & 1.81 & 7.82 & 2.12 & 15.40 & 0.75 & 6.60 & 8.20 & 11.30 \\
\hline 2014 & 7.64 & 22.50 & 30.15 & 39.71 & 52.38 & 8.1 & 2.33 & 7.50 & 2.20 & 15.50 & 0.75 & 6.78 & 8.02 & 11.20 \\
\hline
\end{tabular}

Table 2. Chemical properties of the 3 samples of sanitary water used in both seasons.

\begin{tabular}{|c|c|c|c|c|c|c|c|c|c|c|c|c|c|c|c|c|}
\hline \multirow{2}{*}{ Sample } & \multirow{2}{*}{$\begin{array}{c}\text { Ec } \\
(\mathrm{ds} / \mathrm{m})\end{array}$} & \multirow{2}{*}{ pH } & \multicolumn{4}{|c|}{ Cations (meq/l) } & \multicolumn{3}{|c|}{ Anions (meq/l) } & \multicolumn{7}{|c|}{ Heavy metals (ppm) } \\
\hline & & & $\mathrm{Ca}^{++}$ & $\mathbf{M g}^{++}$ & $\mathbf{N a}^{+}$ & $\mathbf{K}^{+}$ & $\mathrm{HCO}_{3}^{-}$ & $\mathrm{Cl}^{-}$ & $\mathrm{SO}_{4}^{--}$ & $\mathrm{Fe}$ & $\mathbf{Z n}$ & Mn & $\mathrm{Cu}$ & Co & Cd & $\mathbf{P b}$ \\
\hline 1 & 0.66 & 8.40 & 1.74 & 1.19 & 0.72 & 3.01 & 2.56 & 2.81 & 1.29 & 0.99 & 0.46 & 0.05 & 0.90 & 0.002 & 0.012 & 0.072 \\
\hline 2 & 0.79 & 9.00 & 1.50 & 1.88 & 1.33 & 2.10 & 1.97 & 2.96 & 1.88 & 0.86 & 0.67 & 0.03 & 1.00 & 0.004 & 0.015 & 0.063 \\
\hline 3 & 0.71 & 8.76 & 1.62 & 1.55 & 1.04 & 2.60 & 2.30 & 2.58 & 1.93 & 0.93 & 0.56 & 0.04 & 0.95 & 0.003 & 0.013 & 0.068 \\
\hline
\end{tabular}

Table 3. Detection of pathogenic indicators, Salmonella $\&$ tshigella and human parasites in the three samples of sanitary water used in both seasons.

\begin{tabular}{|c|c|c|c|c|c|c|c|}
\hline \multirow{2}{*}{ Pathogenic indicators } & \multicolumn{3}{|c|}{ Detection } & \multirow{2}{*}{ Human parasites } & \multicolumn{3}{|c|}{ Detection } \\
\hline & 1 & 2 & 3 & & 1 & 2 & 3 \\
\hline Total coliform becteria & $\mathrm{d}$ & $\mathrm{d}$ & $\mathrm{d}$ & E. Histylotica Cyst. & $\mathrm{d}$ & $\mathrm{d}$ & d \\
\hline Fecal coliform becteria & $\mathrm{d}$ & $\mathrm{d}$ & $\mathrm{d}$ & G. lamblea & $\mathrm{d}$ & $\mathrm{d}$ & nd \\
\hline Salmonella \& tshigella & $\mathrm{d}$ & nd & $\mathrm{d}$ & E. coli, Round-and Hook worms & $\mathrm{d}$ & $\mathrm{d}$ & $\mathrm{d}$ \\
\hline
\end{tabular}

$\mathrm{d}=$ detected, and $\mathrm{nd}=$ non detected.

Data were then tabulated and the morphological ones were subjected to analysis of variance using SAS Institute program (1994) followed Duncan's Multiple Range Test (Duncan, 1955) to elucidate the significancy among various treatments.

\section{RESULTS AND DISCUSSION}

Part I. Effect of water type, jasmine oil and their interaction on growth and chemical composition of Casuarina equisetifolia $\mathbf{L}$. plants:

\section{1- Effect on vegetative and root growth characters:}

It is evident from data averaged in Tables (4 a and b) and (5) that mixed water treatment significantly improved all vegetative and root growth traits over control in the two seasons, while irrigation with sanitary water gave values of some traits closely near to those of control with non- significant differences among them despite improving fresh and dry weights of stem, leaves and roots relatively better than control in both seasons. On the other side, a progressive increment was observed in means of all vegetative and root growth parameters as a result of spraying with the gradual increasing in jasmine oil concentration to reach the maximum by $0.05 \%$ level in the two seasons. Combining between water type and jasmine oil spraying greatly improved growth performance, with the superiority of connecting between mixed water irrigation and $0.05 \%$ jasmine oil spraying, as this combination recorded the utmost high means of various vegetative and root growth criteria over the other combinations in the two seasons. In general, the least growth rate was noticed in plants irrigated with $100 \%$ sanitary water in the absence of jasmine oil treatment. 

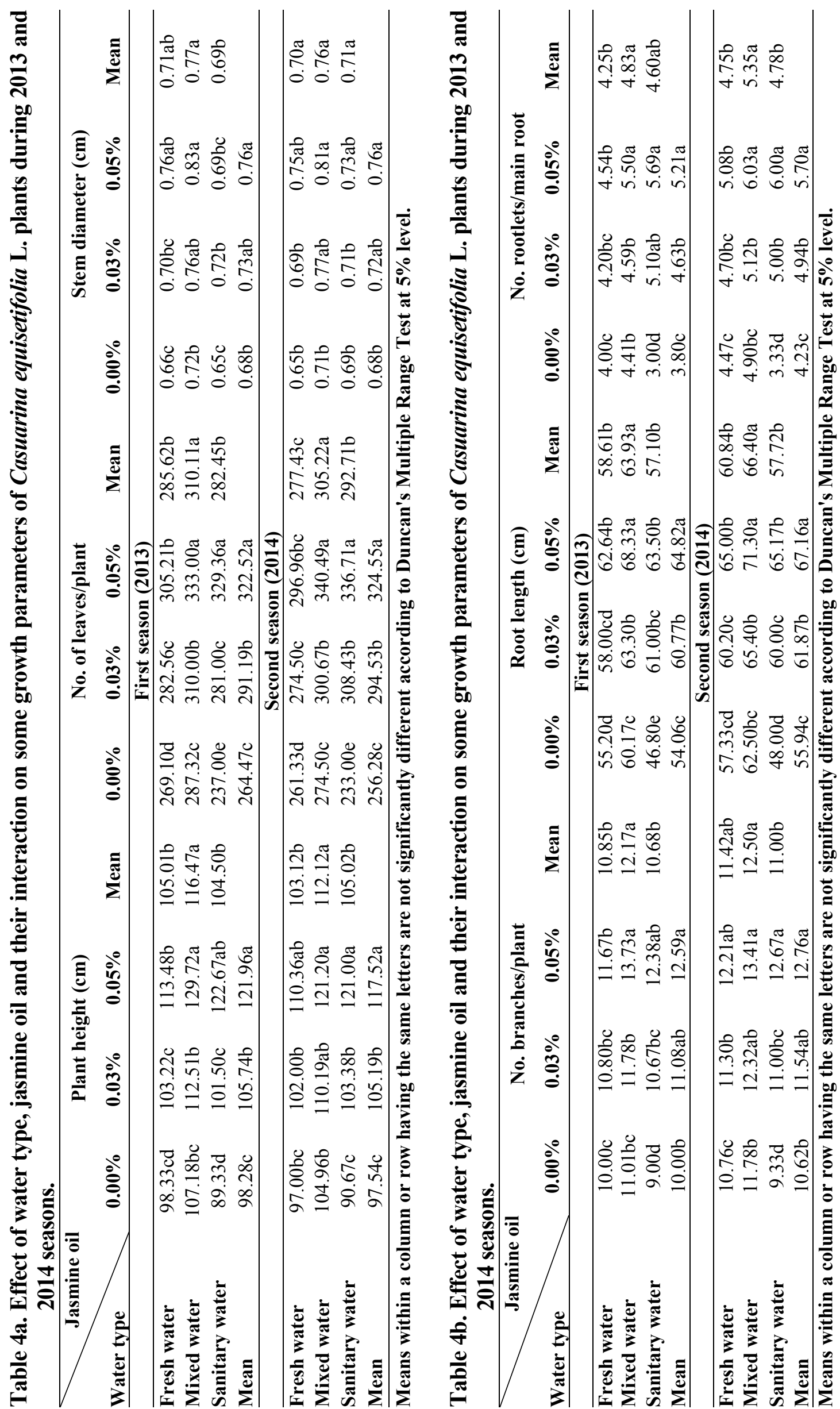
S.M. Shahin and A.S. Tawila

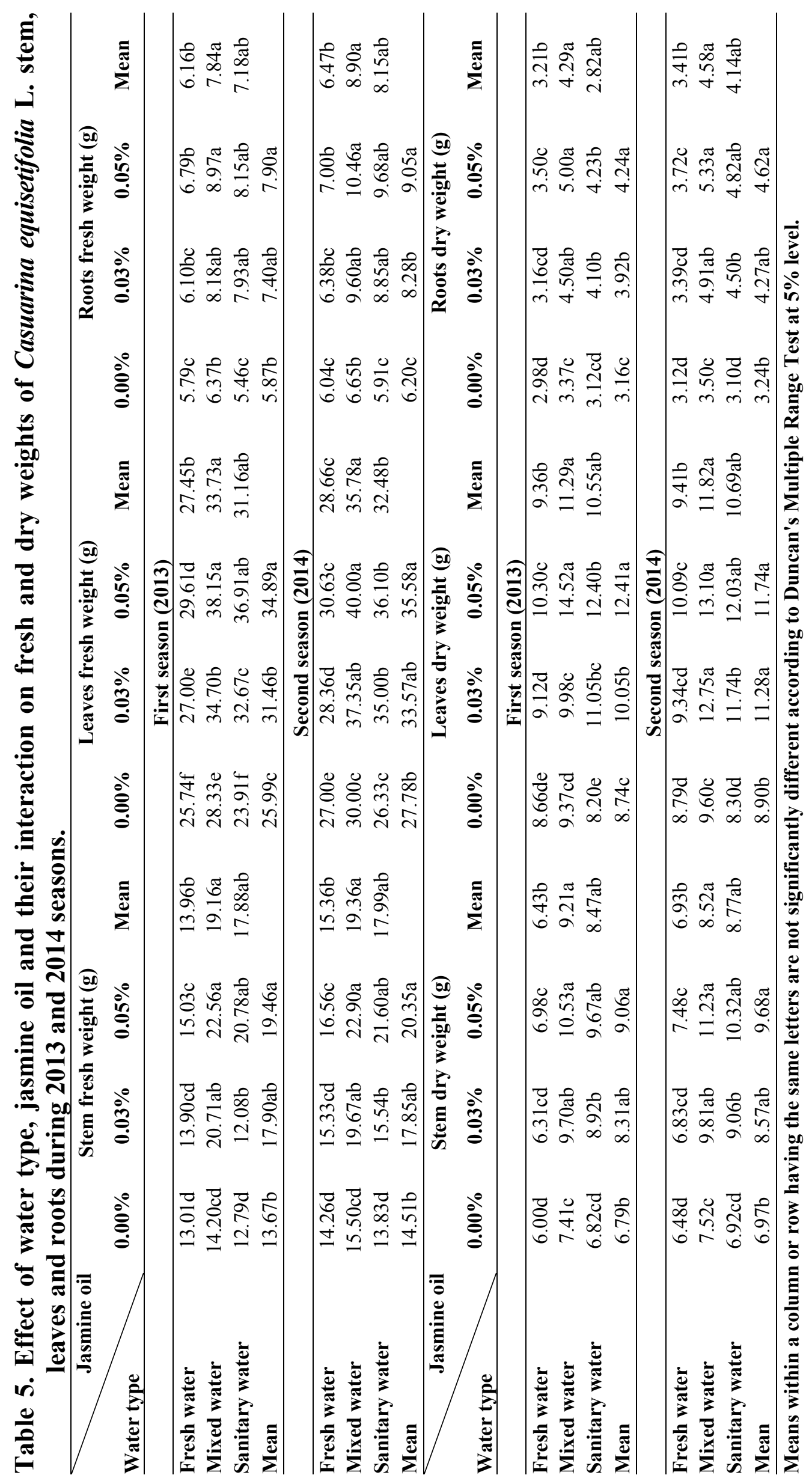


Improvement growth or some growth parameters of plants irrigated with either sanitary or mixed water indicate the direct role of such water types in correcting soil fertility by adding some nutrients and organic matter, which in turn improve soil physical and chemical properties (Verma et al., 1991 and Kanekar et al., 1993), whilst growth reduction may be refer to accumulation of some toxic elements which may cause chlorosis, leaf defoliation and some physiological disorders (Gogate et al., 1995), or may be due to contamination with some pathogens and parasites that cause some diseases which negatively affecting growth and health of plants (Norman et al., 2003). Analogous observations were also attained by Poraas (2000) on Eucalyptus batryoides and Casuarina tenussima, Hassan (2005) on Khaya senegalensis, Swiettenia mahogony and Taxodium distichum, Abdalla (2007) on Strelitzia reginae and Dianthus caryophyllus and Odindo et al. (2013) who reported that bean (Phasealus vulgaris) seeds germinated using waste effluent showed radicle protrusion earlier than those under tap water, radicles were longer and produced more root mass compared to those germinated using tap water. Swiss chard (Beta vulgaris) plants irrigated with waste effluent gave better dry matter and leaf area than those irrigated with tap water.

Besides, jasmine oil activates vital processes in the treated plants, involved in most events of plant development and plays a marked cell signaling role in defensive responses of plants (Moreira et al., 2012 and Lombardero et al., 2013). It is able to regulate ethylene biosynthesis, reduce injuries of the environmental stresses, induce stomatal closure (Kondo, 2010) and decrease chilling injury (Gonzalez-Aquilar et al., 2003). The previous gains, however were supported by those of Naidoo et al. (2013) on Eucalyptus grandis, Boeckler et al. (2013) on Populus nigra and Sunil et al. (2014) on loquat.

\section{2- Effect on chemical composition:}

Data in Table (6) exhibit that chlorophyll $\mathrm{a}, \mathrm{b}$ and carotenoids content in the leaves (mg/g f.w.) was greatly increased relative to control content in response to either mixed or sanitary water treatments, with the prevalence of the former one, which registered the highest content at all. This may be ascribed to presence of macro-and micro-nutrients and organic matter in sanitary or mixed water, which are necessary for promoting stroma lamella formation and grana and chlorophyll appearance during normal leaf growth.

On the other hand, means of these pigments were linearly increased with increasing jasmine oil concentration except of chlorophyll b content which pronouncedly decreased to be 0.149 and $0.232 \mathrm{mg} / \mathrm{g}$ f.w. in the leaves of plants sprayed with 0.03 and $0.05 \%$ concentrations, respectively against $0.388 \mathrm{mg} / \mathrm{g}$ f.w. in the leaves of untreated plants. Increment content of some pigments might be reasonably excepted because jasmine oil usually activates some enzymatic systems in plant tissues which affect the biosynthesis of active constituents in these tissues (Beale and Ward, 1998). In this connection, Tamari et al. (1995) declared that jasmontes induced the pigmentation and flavonoid gene expression in Petunia hybrida corollas. This was also affirmed by Kondo (2010) who found that npropyl dihydrogasmonate application increased coloration of apples fruits. Interactions also enhanced pigments formation, with the mastery of mixed water treatment that scored the highest content of chlorophyll a and carotenoids in the leaves of plants sprayed with $0.05 \%$ jasmine oil solution. That was true for chlorophyll $b$ content when plants were also irrigated with mixed water, but in the absence of jasmine oil treatment.

Results of total soluble sugars, N, P and $\mathrm{K}$ percentages recorded in Tables ( 7 and 8 ) showed a similar trend to that of pigments, as the content of these components clearly increased in the stem, leaves and roots as a results of using either sanitary water (alone or in a mixture) or spraying the foliage with jasmine oil solution. The highest content of them was also due to the connecting between 
S.M. Shahin and A.S. Tawila

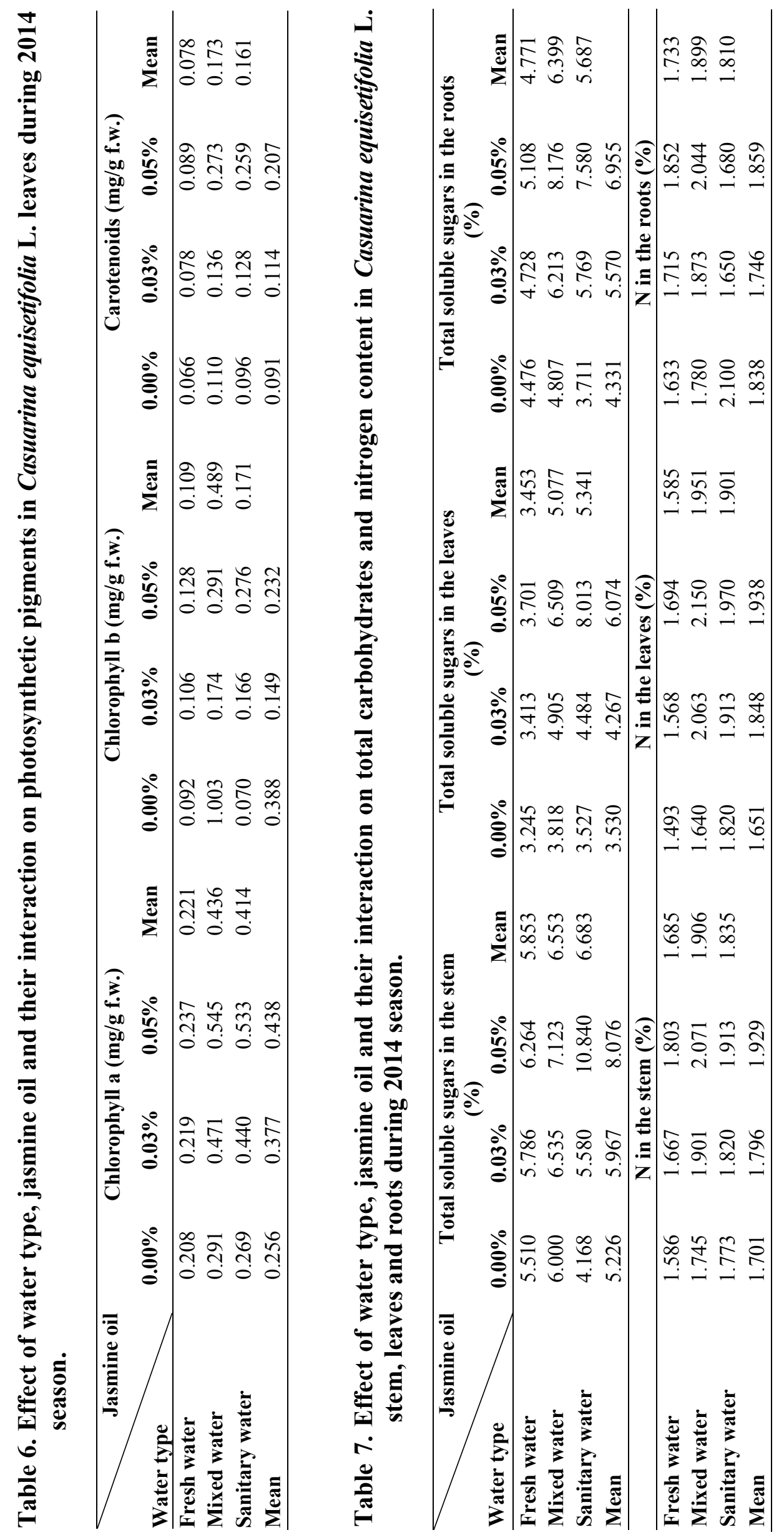




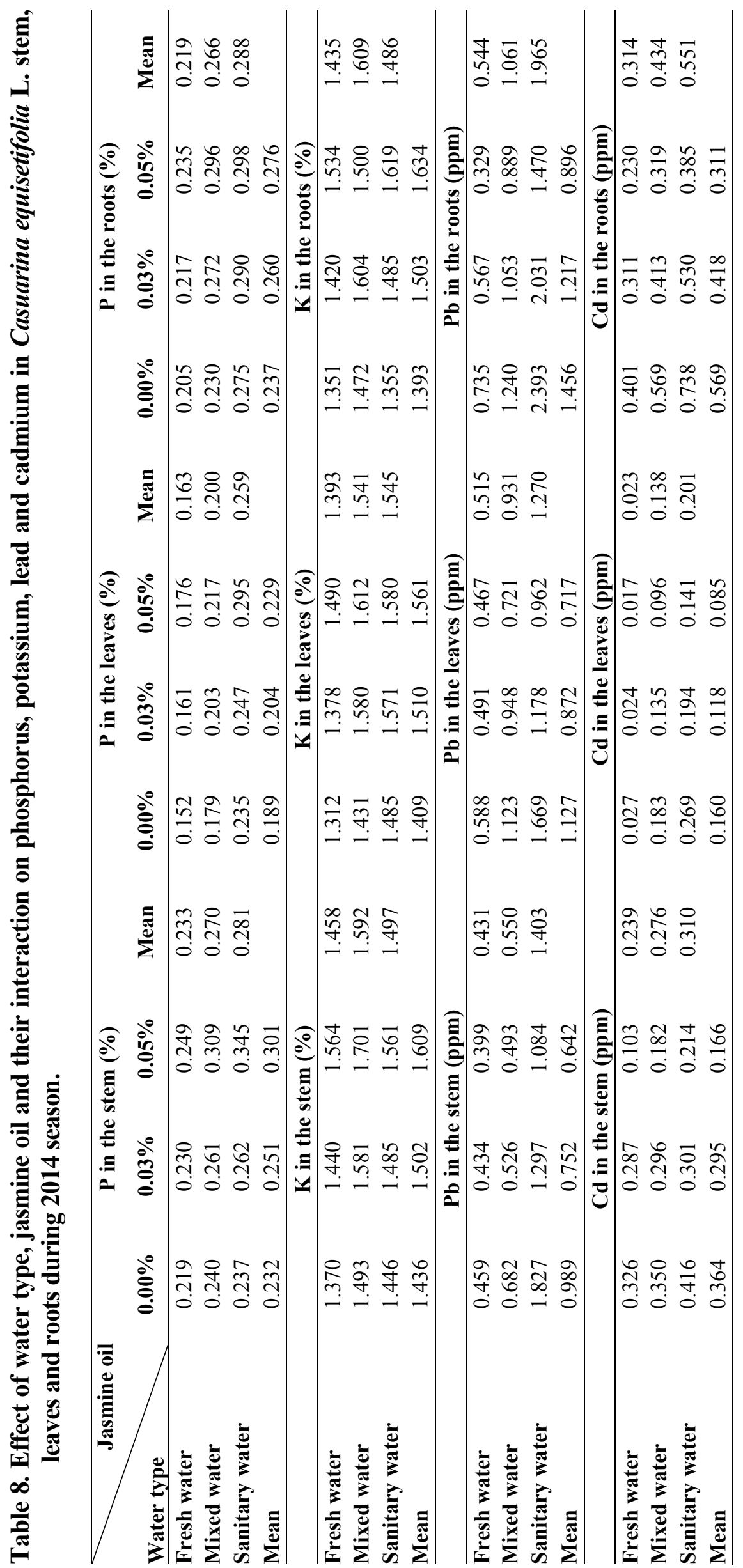


irrigation with mixed water and spraying with jasmine oil at high rate $(0.05 \%)$. Moreover, mixed water often gave higher content of such constituents than sanitary one and content of them was progressively raised as the level of jasmine oil was increased. In this regard, Ozturk (2013) indicated that jasmine oil slow some vital processes such as respiration, while enhance juvenility leading to consumption of sugars by hindering ethylene action and retarding the quick senescence of plant organs, and in turn utilization of sugars. However, the least averages of these constituents were attained by control plants with few exceptions.

The content of $\mathrm{Pb}$ and $\mathrm{Cd}$ in the stem, leaves and roots (ppm) was gradually increased with increasing the percent of sanitary water in irrigation water to reach the maximum when the absolute sanitary water was used for irrigation. This, of course attributed to the presence of these metals in mixed or sanitary water used in this study (Table, 2). In this concern, Hunshal et al. (2000) noted that increasing chemical constituents in plant tissues may be refer to the higher content of suspended solids, solutes and total $\mathrm{N}$ in the used sanitary water. The opposite was the right concerning jasmine oil treatments which were progressively reduced content of such two elements in the different plant organs with increasing its concentration in spray solution. Therefore, the least content of both $\mathrm{Pb}$ and $\mathrm{Cd}$ was noticed in organs of plants sprayed with the high rate of jasmine oil $(0.05 \%)$, especially under fresh water treatment, while the highest content explored in plants irrigated with $100 \%$ sanitary water and received no jasmine oil treatment. Generally, accumulation of $\mathrm{Pb}$ and $\mathrm{Cd}$ in the roots was, to some extent higher than their accumulation in the stem and leaves, but this did not lead to any morpho- or phsio-logical disorders in plants because the concentrations of them did not surpassed the critical levels, which were 30-35 ppm for both as mentioned by Macnicol and Bockett (1985).
The trend of previous results, however, coincides with those postulated by Abbas (2002) on Casuarina glauca, Shahin and ElMalt (2006) on Acacia nilotica,Quercus suber and Tipuana tipu, Semiz et al. (2012) on Pinus sylvestris and Quercus ilex, Ozturk et al. (2013) on "Fuji" apples and Odindo et al. (2013) who mentioned that high $\mathrm{P}$ concentration in the waste effluent may be associated with increased $\mathrm{P}$ content, shoot mass and extensive root growth of bean and Swiss chard.

\section{Part II. Effect of water type, jasmine oil and their interaction on growth and chemical composition of Eucalyptus rostrata Schlecht. plants.}

\section{1- Effect on vegetative and root growth parameters:}

Similar observations to those obtained in case of vegetative and root growth parameters of Casuarina plant (Part I) were also gained in Eucalyptus, where all vegetative and root growth measurements presented in Tables (9 a and b) and (10); expressed as plant height $(\mathrm{cm})$, number of branches and leaves/plant, stem diameter $(\mathrm{cm})$, root length $(\mathrm{cm})$, number of rootlets/main root as well as fresh and dry weights of stem, leaves and roots $(\mathrm{g})$ were improved due to irrigation with either mixed or sanitary water, with the excellence of the former treatment (mixed water) which gave the utmost high values compared to the values recorded by sanitary water in most instances of both seasons. Also, the means of such criteria were cumulatively elevated with rising jasmine oil concentration to be significantly higher than those of control with few exceptions in the two seasons. However, the mastership in both seasons was also for the high rate $(0.05 \%)$. Concerning the effect of interaction treatments, they were caused a marked improve in the different growth traits, with the dominance of the interaction between mixed water treatment and spraying with jasmine oil at $0.05 \%$ level, which gave the best growth in the two seasons at all. On the other hand, the least records were registered 


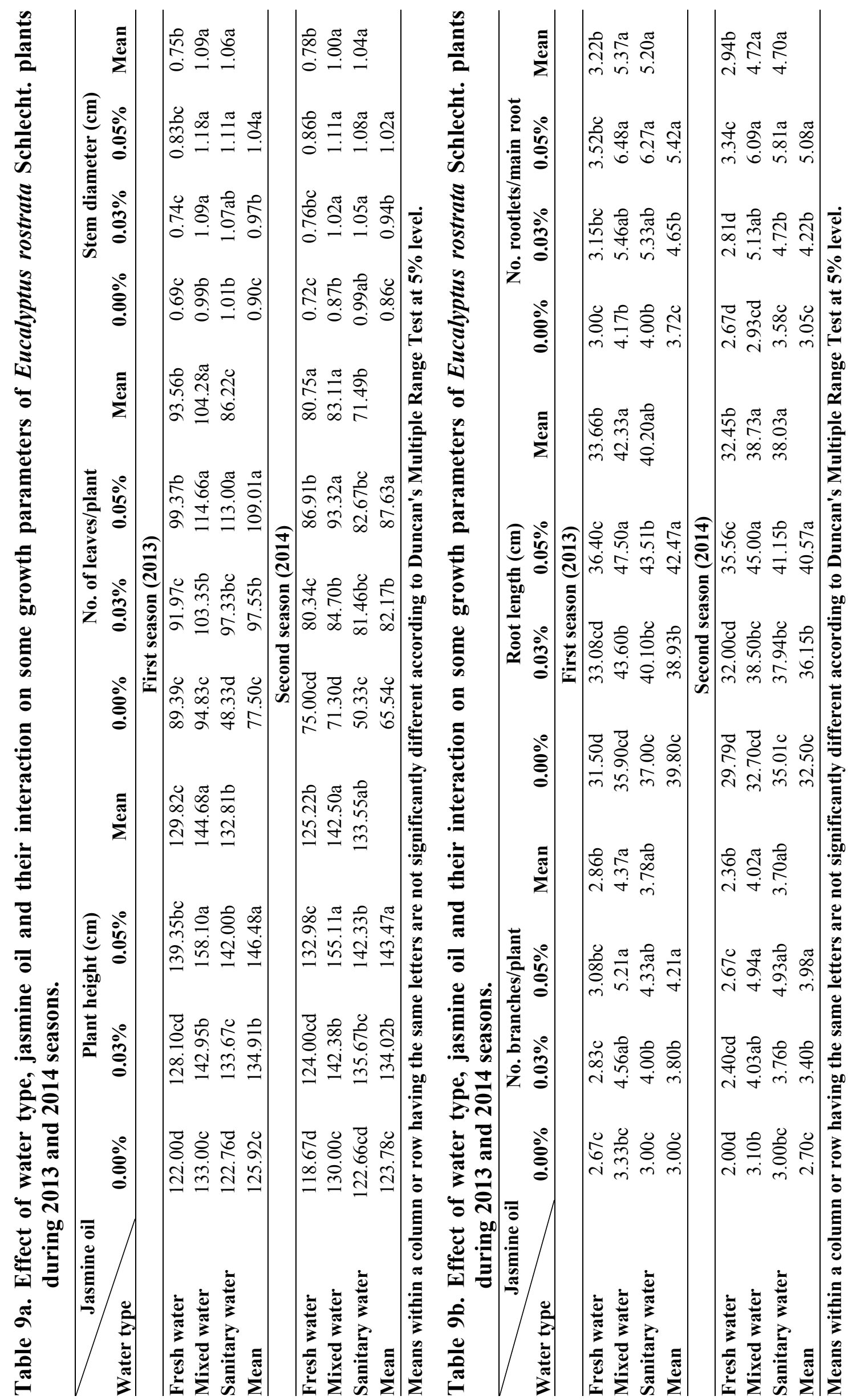


S.M. Shahin and A.S. Tawila

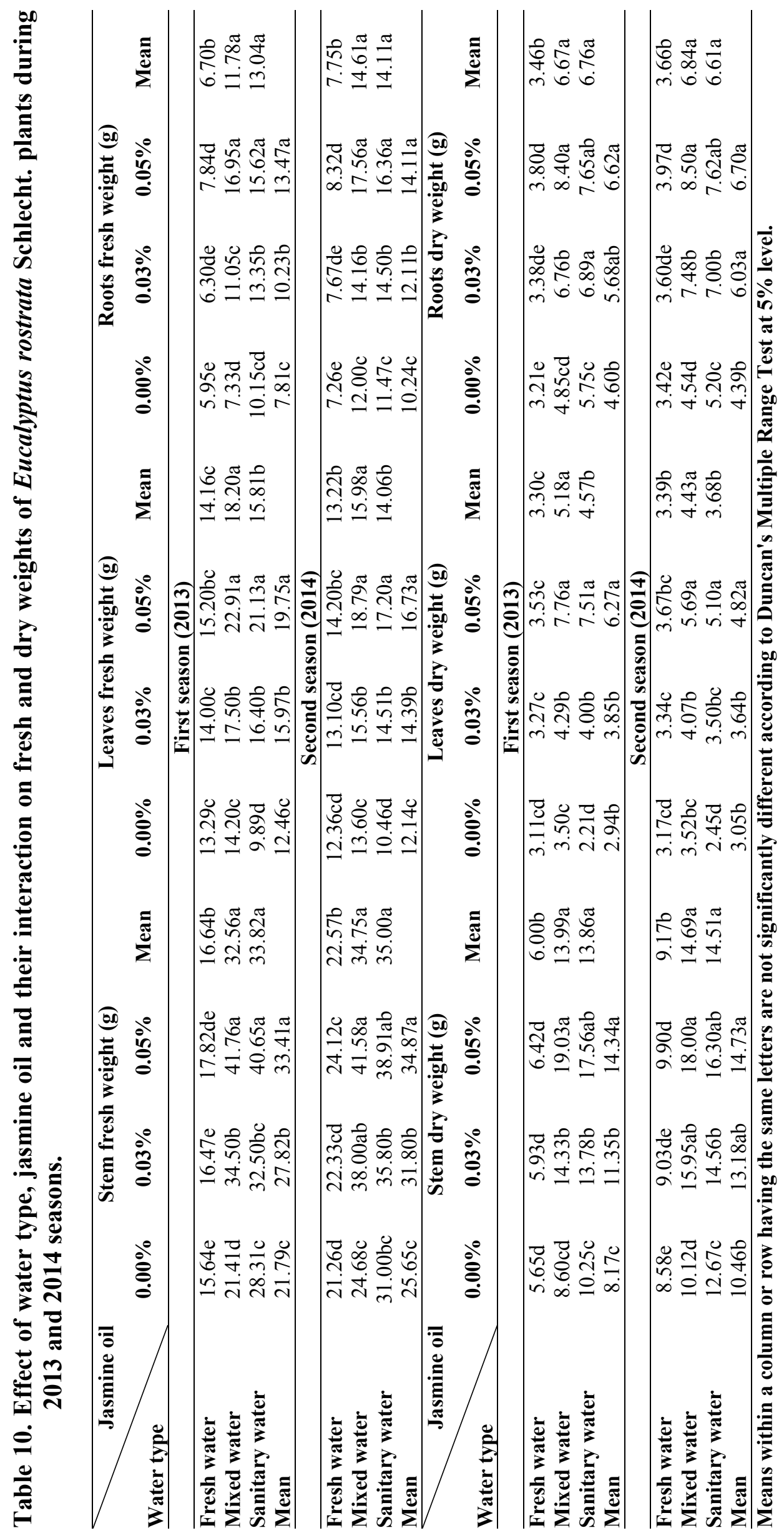


by plants irrigated with $100 \%$ sanitary water and abandoned of jasmine oil solution.

These results could be interpretted and discussed as done before in case of vegetative and root growth parameters of Casuarina plants.

\section{2- Effect on chemical composition:}

It is clear from data illustrated in Table (11) that mixed water is the only treatment among water types which improved chlorophyll a and carotenoids content (mg/g f.w.) in the leaves of plants irrigated with it, whereas sanitary water diminished their content to less than control. As for chlorophyll b content, it was increased by either mixed water or sanitary one recording 0.798 and $0.740 \mathrm{mg} / \mathrm{g}$ f.w. for the two water types, consecutively versus $0.487 \mathrm{mg} / \mathrm{g}$ f.w. for control. The content of these pigments, on the other side were sequentially elevated with elevating jasmine oil concentration to score the high level $(0.05 \%)$ higher values than the low one $(0.03 \%)$. Pigments content was also improved by combined treatments, with the supremacy of mixed water $+0.05 \%$ jasmine oil solution that gave the highest content over other combinations.

Similarly, were the percentages of total soluble sugars, $\mathrm{N}, \mathrm{P}$ and $\mathrm{K}$ contents in the stem, leaves and roots (Tables, 12 and 13), as they were increased in response to the various treatments employed in this work, with the superiority of the individual application of either mixed water or high level of jasmine oil, as well as the interaction between them.

As observed before in case of chemical composition of Casuarina plant, content of both $\mathrm{Pb}$ and $\mathrm{Cd}$ as ppm in the stem, leaves and roots was gradually increased with increasing sanitary water percent in the used water for irrigation, but was linearly decreased with increasing jasmine oil concentration in spray solution. However, the highest content of these two metals was found in the different parts of plants irrigated with absolute sanitary water and sprayed with zero jasmine oil solution. Furthermore, content of such two metals in the roots was higher than that in stem or leaves without any physiological disorders for plants.

The previous findings may be discussed as previously mentioned when the authors discussed these active constituents in case of chemical composition of Casuarina plant (Part, I).

According to the above-mentioned results, it could be noted that sanitary water can be used after mixing it with fresh water in irrigating Casuarina equisetifolia L. and Eucalyptus rostrata Schlecht. plants provided that spraying them with jasmine oil solution at $0.05 \%$ concentration, 3 times with 15 days interval to get the best growth and highest quality.

\section{REFERENCES}

Abbas, M.M. (2002). Effect of Some Heavy Metals in The Irrigation Water on Growth and Chemical Constituents of Some Timber Trees. Ph.D. Thesis, Fac. Agric., Cairo Univ.

Abdalla, M.Y.A. (2007). Usage of sanitary water for production of some cut flowers. J. Agric. Sci., Mansoura Univ., 32(12):10301-10316.

Ahmed, Samira, S.; Shahin, S.M. and ElZayat, H. (2010). Jasmine oil as a natural extract for improving growth and quality of Phoenix and Latania palm transplants rather than chemical fertilization. Egypt. J. Appl. Sci., 25(4B):281-296.

Bailey, L.H. (1976). Hortus Third, Macmillan Publishing Co., Inc., 866 Third Avenue, New York, N.Y. 10022.1290 pp.

Beale, M.H and Ward, J.L. (1998). Jasmonates: Key players in the plant defence. Natural Products Reports, Bristol Univ. UK: 533548.

Boeckler, G.A.; Gershenzon, J. and Unsicker, S.B. (2013). Gypsy moth caterpillar feeding has only a marginal impact on phenolic compounds in oldgrowth black poplar. J. of chemical Ecology, 39(10):1301-1312. 
S.M. Shahin and A.S. Tawila

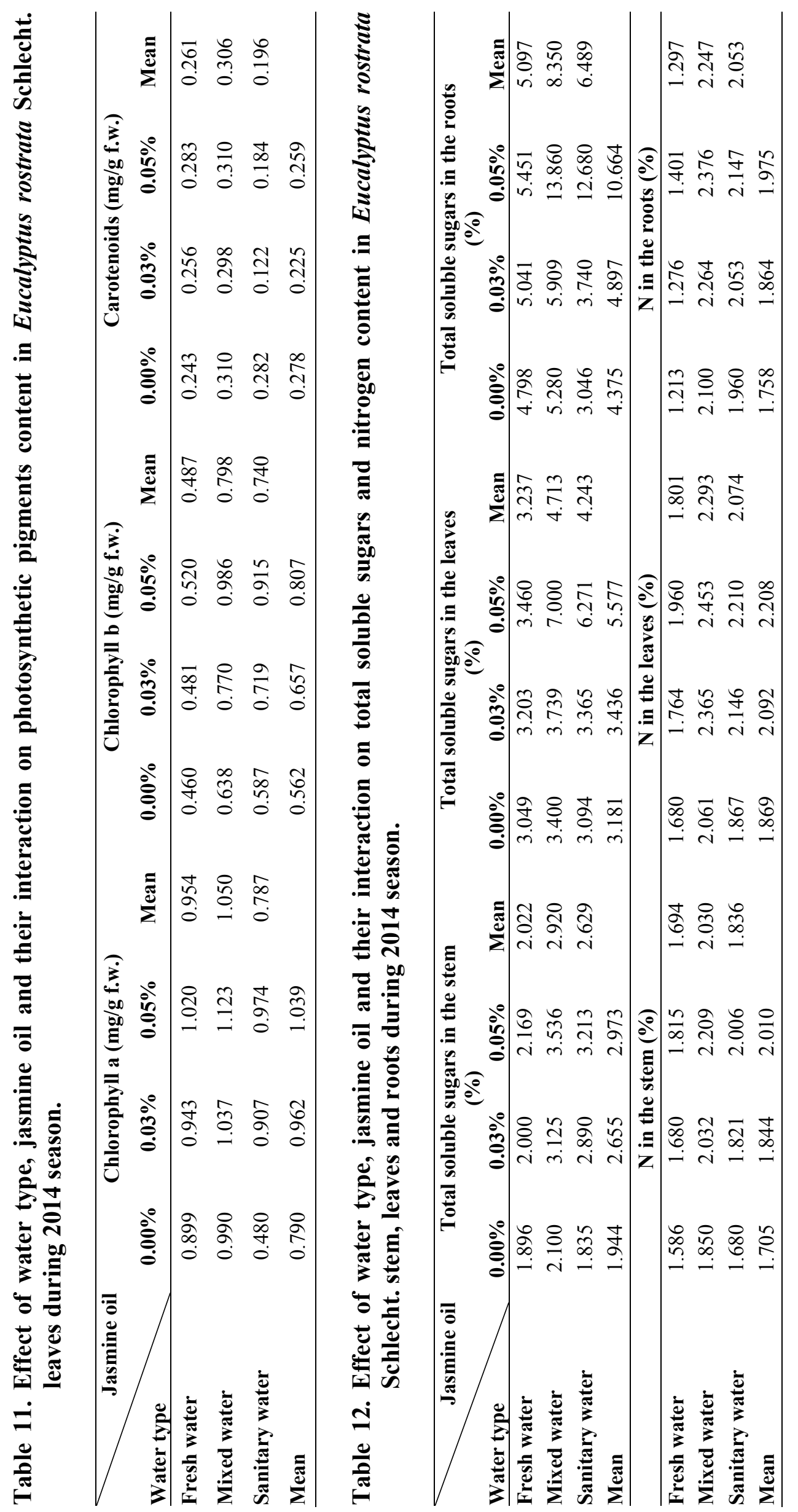




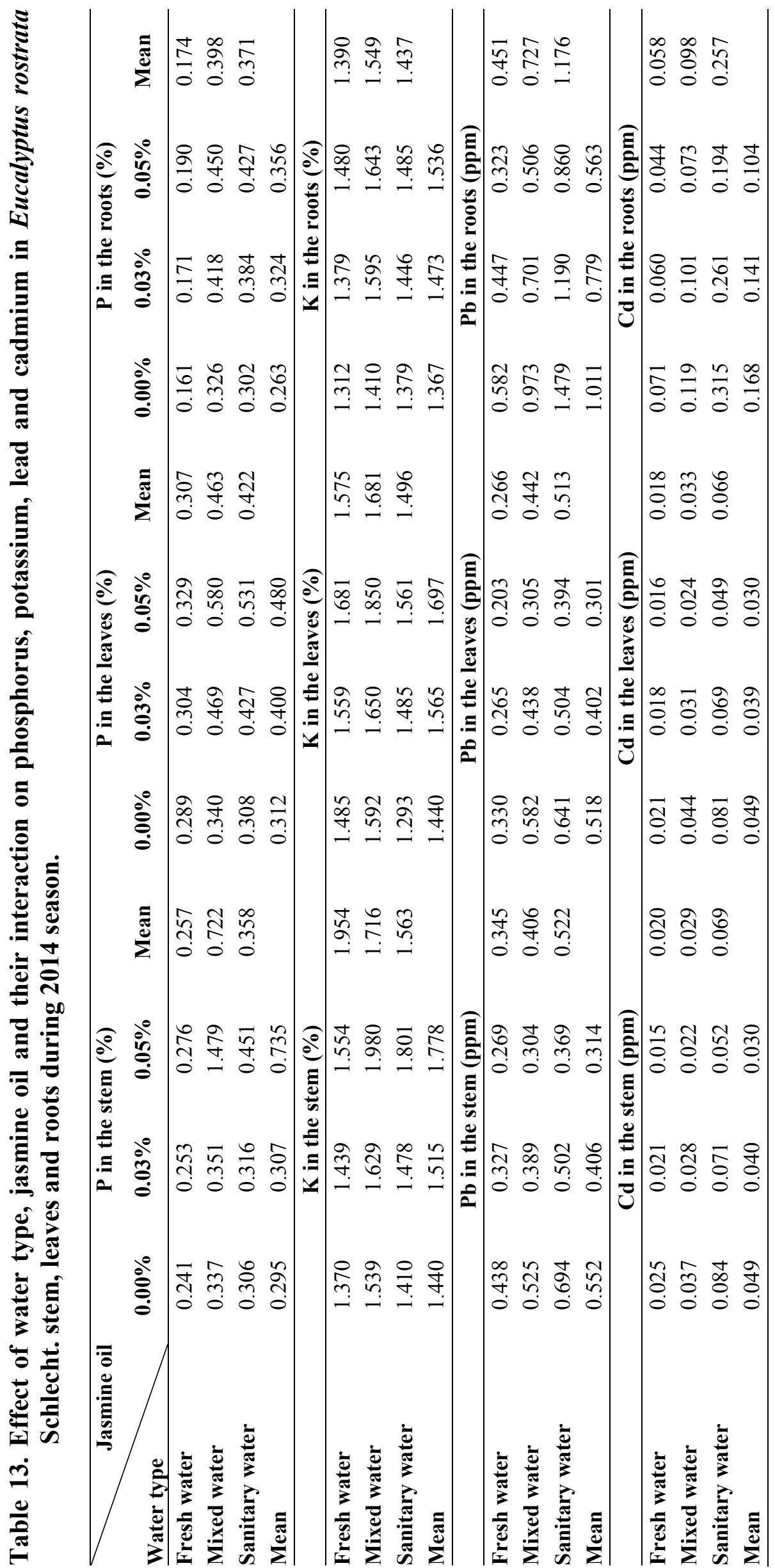


Dubois, M.; Smith, F.; Illes, K.A.; Hamilton, J.K. and Rebers, P.A. (1956). Colorimetric method for determination of sugars and related substances. Ann. Chem., 28(3):350-356.

Duncan, D.B. (1955). Multiple range and multiple F. Tests biometrics ,11:1- 24.

Gogate, M.G.; Farooqui, U.M. and Joshi, V.S. (1995). Sewage water as potential for the tree growth: a study on teak (Tectona grandis) plantation. IndianForester, 121(6):472-481.

Gong, S.; Zhang, Y.; Xue, J.; Du, X. and Xie, Y. (2012). The effect of Me JA treatment and the scale insect attack on the volatile of the jujube trees. J. Biology, 29(5):43-48.

Gonzalez-Aguilar, G.A.; Buta, J.G. and Wang, C.Y. (2003). Methyl jasmonate and modified atmosphere packaging reduce decay and maintain post-harvest quality of papaya. Postharvest Biotech: 28:361-370.

Hassan, H. M. (2005). Effects of Irrigation With Sewage Effluent on Some Trees. M.Sc. Thesis, Fac. Agric., Kafr ElSheikh, Tanta Univ.

Hunshal, C.S.; Salakinkrp, S.R. and Brook, R.M. (2000). Sewage irrigated vegetable production systems around HubliDharwad, Karnataka, India Kasetsart J. Natural Sciences, 32(5):1-8.

Huxley, A.; Griffiths, M. and Levy, M. (1992). The New Royal Hort. Society Dictionary of Gardening. The Stockton Press, 257 Park Avenue South, New York, N. Y. 10010, USA, vol. 2, 747 pp.

Jackson, M.H. (1973). Soil Chemical Analysis. Prentice-Hall of India Private Limited M-97, New Delhi, India, 498 pp.

Kanekar, P.; Kumbhojkar, M.S.; Ghate, V.; Samaike S. and Kelkar A. (1993). Evaluation of Acacia nilatica (L) Del and Casuarina equisetifolia Forst for tolerance and growth on microbially treated dyestuff waste water. Environmental Pollution, 81(1):47-50.
Koda, Y.; Omer, E.A.; Yoshihara, T.; Shibata, H.; Sakamura, S. and Okazawa, Y. (1998). Isolation of a specific potato tuber-inducing substance from potato leaves. Plant cell Physiology, 29:10471051.

Kondo, S. (2010). Roles of jasmonates in fruit ripening and environmental stress. Acta Hort., 884:711-716.

Kondo, S. and Yazama, F. (2004). Changes of abscisic acid and its metabolite during development of apple fruit. J. Amer. Soc. Hort. Sci., 129(2):152-157.

Lombardero, M.J.; Pereira-Espinel, J. and Ayres, M. P. (2013). Foliar terpene chemistry of Pinus pinaster and $P$. radiata responds differently to methyl jasmonats and feeding by larvae of the pine prpcessionary moth. Forest Ecology and Management, 310:935-943.

Lovatt, C.J. and Zheng, Y. (2010). Use of plant bioregulators to stimulate embryo growth and loosen fruit to increase split nut yield of pistachio. Acta. Hort., 884:549-557.

Luatanab, F.S. and Olsen, S.R. (1965). Test of an ascorbic acid method for determining phosphorus in water and $\mathrm{NaHCO}_{3}$ extracts from soil. Soil Sci. Soc. Amer. Proc., 29:677-678.

Macnicol, R. D. and Bockett, P. H. T. (1985). Critical tissue concentrations of potentially toxic elements. Plant and Soil, 85:107-109.

Mead, R.; Curnow, R.N. and Harted, A.M. (1993). Statistical methods in Agriculture and Experimental Biology. $2^{\text {nd }}$ Ed., Chapman \& Hall Ltd., London, 335 pp.

Moran, R. (1982). Formula for determination of chlorophyllous pigment extracted with $\mathrm{N}$, N-dimethyl formamide. Plant physiol; 69:1376-81

Moreira, X.; Zas, R. and Sampedro, L. (2012). Quantitative comparison of chemical, biological and mechanical induction of secondary compounds in Pinus pinaster 
seedlings. Tree: Structure and Function, 26 (2):677-683.

Moreira, X.; Zas, R. and Sampedro, L. (2012). Genetic variation and phenotypic plasticity of nutrient re-allocation and increased fine roots production as putative tolerance mechanism inducible by methyl jasmonate in pine tree. J. of Ecology (Oxford), 100(3):810-820.

Naidoo, R.; Ferreira, L.; Berger, D.K.; Myburg, A.A. and Naidoo, S. (2013). The identification and differential expression of Eucalyptus grandis pathogensis-related genes in response to salicylic acid and methyl jasmonate. Frontiers in Plant Science, 4:43.

Nojiri, H.; Yamane, H.; Seto, H.; Yamagushi, I.; Murofushi, $\mathrm{N}$ and Shibaoka, H. (1992). Qualitative and quantitative analysis of endogenous jasmonic acid in bulbing and non-bulbing onion plants. Plant Cell Physiol., 33:1225-1231.

Norman, D.J.; Yuen, J.M.; Resendiz, R. and Boswell, J. (2003). Characterization of Erwinia populations from nursery retention ponds and lakes infecting ornamental plants in Florida. Plant Disease, 87(2):193-196.

Odindo, A.O.; Ngobese, I.N.; Madlala S. and Tesfay, S.Z. (2013). The potential use of anaerobic baffled reactor (ABR) effluent for peri urban horticulture. Acta. Hort., 1007:295-302.

Ozturk, B.; Altuntas, E.; Yildiz, K.; Ozkan, Y. and Saracoglu, O. (2013). Effect of methyl jasmonate treatments on the bioactive compounds and physiochemical quality of "Fuji" apples. Ciencia Investigaction Agraria, 40(1):201-2011.

Poraas, M.M. (2000). The Environmental Effects of Some Woody Trees Cultivated on Sandy Soil Irrigated With Sewage Water. Ph.D. Thesis, Environmental Studies and Research Inst., Ain Shams Univ.
Pregl, F. (1945). Quantitative Organic microanalysis $4^{\text {th }}$ Ed. J \& A., churvhill, Ltd. London, P. 203-209.

SAS, Institute Program (1994). SAS/STAT User's Guides Statistics. Vers. 6.04, $4^{\text {th }}$ Ed., SAS. Institute Inc. Cary, N.C., USA.

Semiz, G.; Blande, J.D.; Heijari, J.; Isik, K.; Niinemets, U. and Holopainen J.K. (2012). Manipulation of VO Cemissions with methyl jasmonate and carrageenan in the evergreen conifer Pinus sylvestris and evergreen broadleaf Quercus ilex. Plant Biology, 14(s1):57-65.

Shafiq, M.; Singh, Z. and Khan, A.S. (2011). Pre-harvest spray application of methyl jasmonate improves red blush and flavonoid content in "Cripps Pink" apple. J. of Hort. Sci. and Biotech., 86(4):422430.

Shafiq, M.; Singh, Z. and Khan, A.S. (2013). Time of methyl jasmonate application influences the development of "Cripps Pink" apple fruit colour. J. of the Sci. of Food and Agric., 93(3):611-618.

Shahin, S.M. and El-Malt Azza, A. (2006). A study on usage of sant, oak and tipu trees for arboriculture of a polluted sandy soil. Egypt. J. Appl., Sci., 21(7):192-214.

Shahin, S.M. and Poraas, M.M. (2005). Response of Dodonaea viscosa (L.) Jacq transplants to sanitary water irrigation in some soils of Egypt. Egypt. J. Appl., Sci., 20(3):120-139.

Sunil, P.; Benkeblia, N.; Janick, J.; Cao, S. and Yahina, E.M. (2014). Postharvest physiology and technology of loquat (Eriobotrya japonica Lindl.) fruit. J. of the Sci. of Food and Agric., 94(8):14951504.

Tamari, G.; Borochov, A.; Atzorn, R. and Weiss, D. (1995). Methyl jasmonate induces pigmentation and flavonoid gene expression in petunia corollas: a possible role in wound response. Plant Physiol., 94: 45-50. 


\title{
S.M. Shahin and A.S. Tawila
}

Verma, R.S.; Singh, A.K. and Tripathi, N.C. (1991). Irrigating trees with raw sewage water. Indian Farming, 41(1):27-28.

Zabala, M.A.; Angarita, M.; Restrepo, J.M.; Caicedo, L.A. and Perea, M. (2010). Elicitation with methyl jasmonate stimulates peruvoside production in cell suspension cultures of Thevetia peruviana. In vitro Cellular \&
Developmental Biology Plant, 46(3):233238.

Zaky, Amal, A. and El-Zayat, H. (2008). Effect of some ethylene inhibitors on the keeping quality and extending the vase life of carnation (Dianthus caryophyllus L.) cut flowers. Egypt. J. Agric. Res., 86 (1): 243-256.

\section{تقليل الآثار الضارة لمياه الصرف الصحي على نمو وجودة بعض الأثجار ذات القيمة الاقتصادية

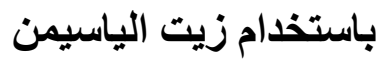

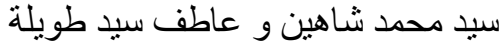 \\ قسم بحوث الحدائق النباتية، معهد بحوث البساتين، مركز البحوث الزر اعية، الجيزة، مصر.
}

أجريت هذه التجربة بالعر اء بمشتل معهذ بحوث البساتين، مركز البحوث الزر اعية، الجيزة، مصر خلال موسمي

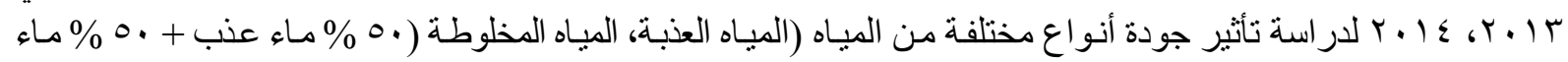

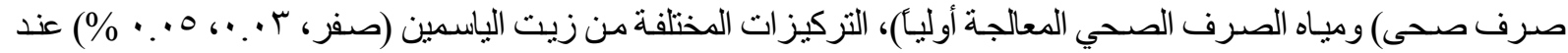

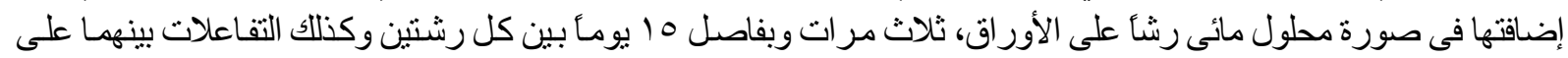

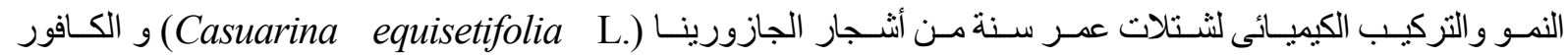
المنزر عة فى أكياس بلاستيك سوداء قطر ها 7 ( 1 سم، ملأت بحو الي ْ. ب كجم (Eucalyptus rostrata Schlecht.)

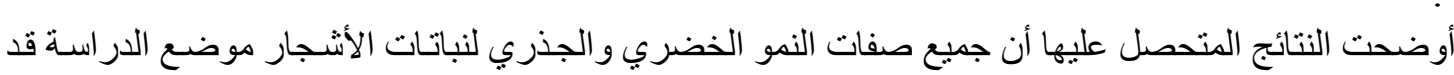
تربة طينية.

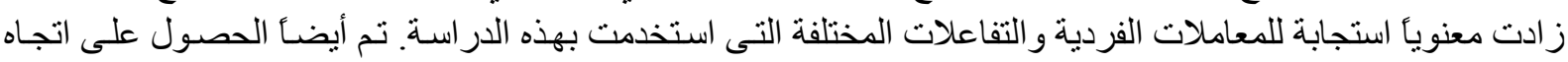

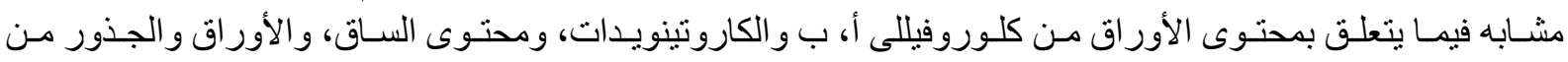

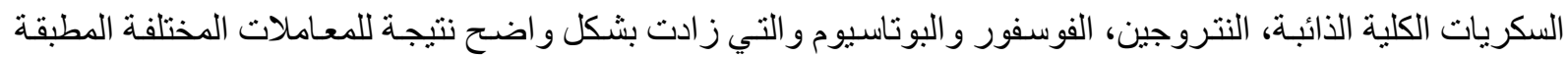
بذهذ الدراسة.

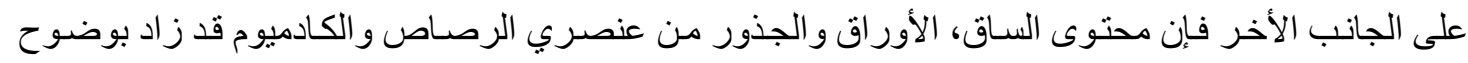

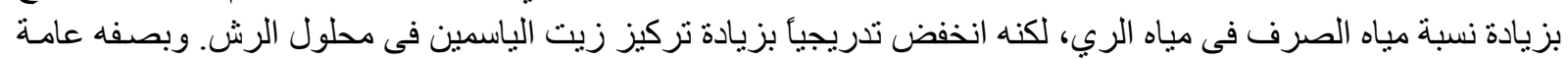

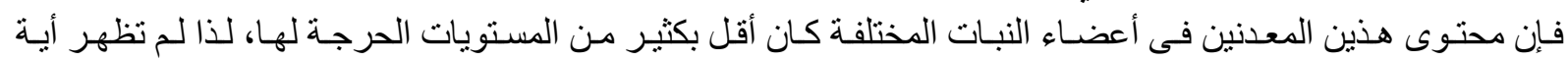

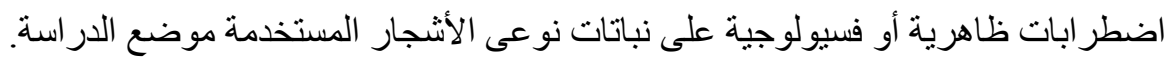

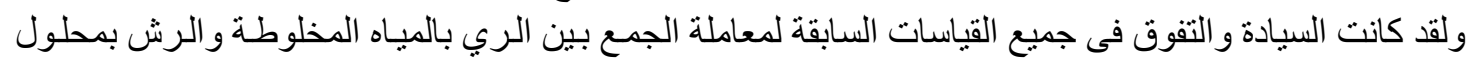

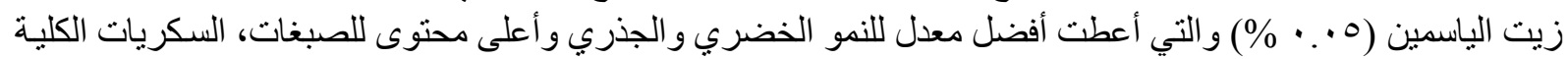

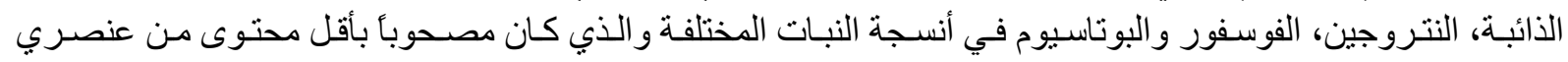

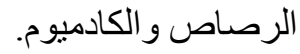

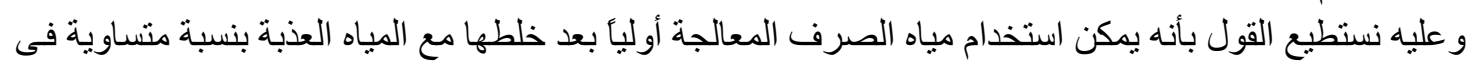

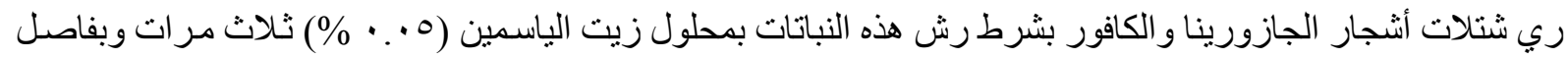
خمسة عشر يو مأ بين كل رشتين للحصول على على أفضل نمو و أعلى جودة. 

